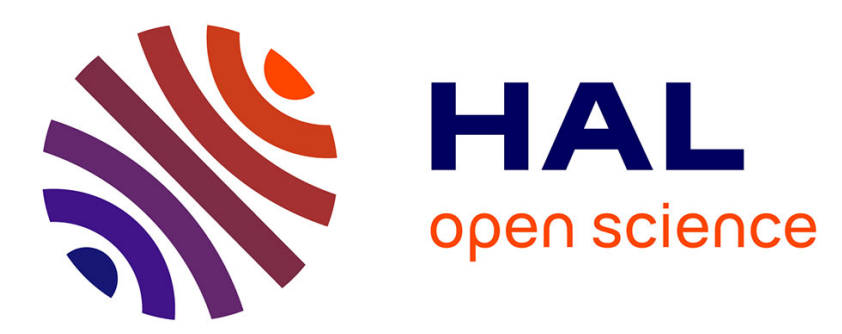

\title{
A nuclear budding mechanism in transiently arrested cells generates drug-sensitive and drug-resistant cells
}

Sylvia Mansilla, Marc Bataller, José Portugal

\section{To cite this version:}

Sylvia Mansilla, Marc Bataller, José Portugal. A nuclear budding mechanism in transiently arrested cells generates drug-sensitive and drug-resistant cells. Biochemical Pharmacology, 2009, 78 (2), pp.123. 10.1016/j.bcp.2009.03.027 . hal-00493511

\section{HAL Id: hal-00493511 https://hal.science/hal-00493511}

Submitted on 19 Jun 2010

HAL is a multi-disciplinary open access archive for the deposit and dissemination of scientific research documents, whether they are published or not. The documents may come from teaching and research institutions in France or abroad, or from public or private research centers.
L'archive ouverte pluridisciplinaire HAL, est destinée au dépôt et à la diffusion de documents scientifiques de niveau recherche, publiés ou non, émanant des établissements d'enseignement et de recherche français ou étrangers, des laboratoires publics ou privés. 


\section{Accepted Manuscript}

Title: A nuclear budding mechanism in transiently arrested cells generates drug-sensitive and drug-resistant cells

Authors: Sylvia Mansilla, Marc Bataller, José Portugal

PII: $\quad$ S0006-2952(09)00254-8

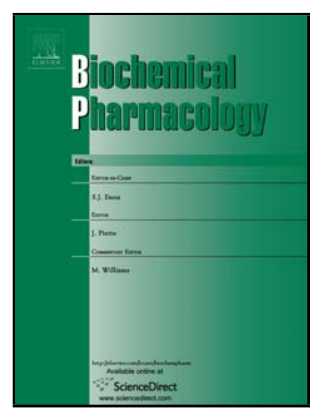

DOI: doi:10.1016/j.bcp.2009.03.027

Reference: BCP 10133

To appear in:

$B C P$

Received date:

24-2-2009

Revised date:

25-3-2009

Accepted date:

Please cite this article as: Mansilla S, Bataller M, Portugal J, A nuclear budding mechanism in transiently arrested cells generates drug-sensitive and drug-resistant cells, Biochemical Pharmacology (2008), doi:10.1016/j.bcp.2009.03.027

This is a PDF file of an unedited manuscript that has been accepted for publication. As a service to our customers we are providing this early version of the manuscript. The manuscript will undergo copyediting, typesetting, and review of the resulting proof before it is published in its final form. Please note that during the production process errors may be discovered which could affect the content, and all legal disclaimers that apply to the journal pertain. 


\section{A nuclear budding mechanism in transiently arrested cells generates drug- sensitive and drug-resistant cells}

Sylvia Mansilla, Marc Bataller and José Portugal*

Instituto de Biología Molecular de Barcelona, CSIC, Parc Cientific de Barcelona, Baldiri Reixach, 10, E-08028 Barcelona, Spain

*Corresponding author:

Dr. José Portugal

Instituto de Biologia Molecular de Barcelona, CSIC

Parc Cientific de Barcelona

Baldiri Reixach, 10

E-08028 Barcelona

Spain

Tel: +34-93-403 4959 (office)

+34-93-403 4963 (lab.)

FAX: +34-93-403 4979

E-mail: jpmbmc@ibmb.csic.es 


\begin{abstract}
HCT116 $\left(\mathrm{p} 53^{+/+}\right)$human colon carcinoma cells treated with nanomolar concentrations of doxorubicin underwent transient senescence, synthesized DNA, showed endopolyploidization, increased their size and became multinucleated without a significant increase in mitosis. Nuclei underwent a budding process that involved the release of buds outside the nuclear membrane, and some of the buds seemed to escape from the polyploid cells. A clonogenic assay showed that some cells proliferated following the initial treatment. In general, cells ensuing after budding were not resistant to a variety of drugs, although some of them turned out to be resistant, indicating a potential selective advantage. Nuclear budding was accompanied by changes in protein levels in the giant cells, including inhibition of p53 and enhanced expression of p $21^{\text {WAF1 }}$ and the meiosis-related Mos. The buds might be a mechanism for the segregation and elimination of redundant DNA, or for generating viable aneuploid cells with a potentially extended life span.
\end{abstract}

Keywords: Aneuploidy; HCT116 cells; p21 ${ }^{\mathrm{WAF}}$; mitotic catastrophe; neosis; senescence

\title{
1. Introduction
}

Cell cycle progression is regulated by checkpoint controls, which protect the genome integrity. These checkpoints prevent cell cycle progression until the preceding events are finished, or DNA damage has been repaired [1,2]. Mitosis is a short phase of the cell cycle strictly controlled by temporally expressed proteins. These usually act together with other post-transcriptional modified proteins that are present throughout the cell cycle $[1,3,4]$. The presence of weakened checkpoints is prevalent in tumor cells [1,5], which can promote aneuploidy.

Apoptosis protects cells from aneuploidy $[1,6]$, but tumor cells usually have defective apoptotic pathways, thus they may enter mitosis that is prolonged for extended periods of time, or the cells may be committed to dying by mitotic catastrophe, which can be induced by caspasedependent or caspase-independent mechanisms [7]. Moreover, some cells can overcome such a defective mitosis but they are halted in the ensuring G1 phase; an arrest that is considered to be p53-dependent $[8,9]$. Senescence is defined as a cell program of terminal growth arrest that can be activated after chemotherapy [10]. Senescence is considered largely p53-dependent, while the onset of mitotic catastrophe is not [11,12]. Several DNA-binding drugs have been reported to produce mitotic catastrophe in both cells containing wild-type $\mathrm{p} 53$ and those bearing mutated or deleted $p 53$ genes [13-17]. Mitotic catastrophe occurs in tumor cells treated with various antitumour drugs or radiation [7, 13,14, 16-21]. These antitumour agents can also limit tumor growth through accelerated senescence arrest [10, 12, 13, 22]. Mitotic catastrophe occurs as a 
consequence of the uncoupling of the onset of mitosis from DNA replication, but how the resulting lethality is regulated is not completely known. Because it is sometimes followed by caspase-dependent cell death, it may be also considered a special case of apoptosis [14, 23]. Senescence-like growth arrest may be followed by mitotic catastrophe once the cells re-enter the cell cycle after drug treatment $[13,14]$. Senescence may also follow mitotic catastrophe if polyploid cells are arrested in G1 or G2 after mitotic catastrophe [13, 24], but the arrest is not permanent when, for example, cells lack $\mathrm{p} 53$ function, or the $\mathrm{p} 53$ and $\mathrm{p} 21^{\mathrm{WAF} 1}$ protein levels decrease after treatment with certain drugs [7, 11, 13, 21, 22, 25], or as a result of alterations in the phosphorilation of Chk1 [19]. Therefore, cells can re-enter the cell cycle, increasing their polyploidy before they eventually die. Some of those cells may escape cell death and undergo further polyploidization [26]. DNA damage may provide the molecular background to trigger entry into an endocycle instead of mitosis [27], which also explains the presence of large multinucleated cells. These cells may facilitate cell survival [28], and their presence has thus been linked to a poor response to chemotherapy.

G2 arrest caused by DNA damage may provide the molecular conditions to trigger the onset of endoreduplication, while $\mathrm{p} 21^{\mathrm{WAF} 1}$ may concomitantly suppress the DNA damage response [29]. It has been suggested that giant senescent cells can undergo a type of cell division known as neosis $[26,30]$, which is characterized by a peculiar karyokinesis that occurs via nuclear budding, followed by asymmetric intracellular cytokinesis that would produce small cells, termed Raju cells, with stem-cell-like characteristics and extended life span [26]. It has been hypothesized that neosis is a mechanism of recurrent growth of resistant tumor cells after chemotherapy [26]. During neosis, the spindle checkpoint would not be activated, which may give rise to aneuploidy [26]. The prospect that endopolyploid tumor cells may have survival potential [31] remains controversial [23]. It has not been established whether neosis is a mechanism that evades cell death via mitotic catastrophe and whether Raju cells could facilitate tumor self-renewal, and thus allow recurrent growth of resistant tumor cells after chemotherapy. Aberrant chromosomal structures in aneuploid cells can generate nuclear projections referred to as 'buds', while the frequency of nuclear budding and micronucleation is increased by inactivating p53, suggesting that p53 would minimize the probability of forming broken chromosomes [32]. Some of the formed buds may lead to the appearance of micronuclei enriched in extrachromosomically amplified DNA. In addition, their formation may be followed by the elimination of redundant DNA, which will be consistent with the hypothesis that a non-selective DNA damage can lead to the elimination of extrachromosomal material from human cancer cells [33]. 
We sought to gain new insights into the relationship between mitotic catastrophe, senescence and the presence of multinucleated cells, sometimes also containing micronuclei. We have used HCT116 human colon carcinoma cells that contain wild-type 53, treated with low nanomolar concentrations of doxorubicin, which do not trigger the apoptotic response. We examined whether a nuclear budding can generate aneuploid Raju cells. Moreover, we also explored whether the HCT116 (p53 $3^{+/+}$) cells that recover, after budding, from a treatment with moderate concentrations of doxorubicin were relatively resistant to treatment with a variety of antitumor agents and become invasive cells or whether they were committed to cell death. Our results suggest that after a nuclear budding procedure some cells recover their growing capacity. It seems that excess DNA was extruded from the nuclei. Cells that eliminated the buds were proliferating and increased their time span. However, these buds should not be considered Raju cells (i.e. small aneuploid cells with stem cell characteristics).

\section{Materials and methods}

\subsection{Drugs}

Doxorubicin, etoposide (VP-16), camptothecin, cisplatin and paclitaxel were were purchased from Sigma (St. Louis, MO). WP631 was a generous gift of Dr. Waldemar Priebe (MD Anderson Cancer Center, Texas). Drug stocks were prepared as $1 \mathrm{mM}$ solutions in sterile $150 \mathrm{mM} \mathrm{NaCl}$ or $100 \% \mathrm{DMSO}$, maintained at $-20^{\circ} \mathrm{C}$, and brought to the final concentration using cell culture media just before use.

\subsection{Cell culture and drug treatments}

HCT116 (p53 $3^{+/+}$) human colon carcinoma cells were maintained in 50\% Dulbecco's MEM (Gibco, Invitrogen, Prat de Llobregat, Spain)/50\% Ham's F12 (Lonza, Barcelona, Spain) medium, supplemented with $10 \%$ fetal bovine serum (Gibco), $100 \mathrm{U} / \mathrm{ml}$ penicillin, $100 \mu \mathrm{g} / \mathrm{ml}$ streptomycin, at $37{ }^{\circ} \mathrm{C}$ in a humidified atmosphere with $5 \% \mathrm{CO}_{2}$. Exponentially growing cells subcultured at a density of $2.5 \times 10^{4}$ cells $/ \mathrm{ml}$ were incubated with low nanomolar doses of doxorubicin at $37^{\circ} \mathrm{C}$ for times indicated in the legend to figures.

\subsection{Cytotoxicity assays}

The effect of the different drugs on HCT116 cell growth was determined by the MTT method using 3-(4,5-dimethylthiazol-2-yl)-2,5-diphenyl tetrazolium (Sigma), following 72-h treatment, as described elsewhere [34].

\subsection{Cell cycle analysis and flow cytometry}


After treatment with doxorubicin for various periods of time, the cells were harvested, fixed with 70\% ethanol, stained with PI (Propidium iodide, Sigma) and nuclei analyzed with a Coulter Epics-XL flow cytometer (Coulter Corporation, Hialeah, FL) as described elsewhere.[34]

To analyze the mitotic fraction, fixed cells were incubated with the anti-phospho-histone H3 (ser 10) antibody (Upstate, Millipore, Madrid, Spain) followed by Cy2-conjugated secondary antibody (Jackson ImmunoResearch, Newmarket, UK). Stained cells were then counterstained with PI and analyzed for Cy2 and PI fluorescence by flow cytometry.

\subsection{Determination of DNA synthesis}

DNA synthesis was assayed by the incorporation of BrdU (5'-Bromo-2'-deoxy-uridine, Roche Diagnostics, Barcelona, Spain) using a fluorescence-conjugated antibody against BrdU (BD Biosciences, Madrid, Spain), and co-stained with PI.

\subsection{Confocal microscopy, time-lapse imaging and immunofluorescence}

HCT116 cells in exponential growth phase were stained, after drug treatment, with either DAPI (Sigma) or Draq5 (Molecular Probes, Invitrogen, Prat de Llobregat, Spain) and rinsed with drug free medium before analysis. Confocal laser microscopy was performed with a Leica confocal TCS-Sp2 AOBS microscope system (Leica Microsystems; Heidelberg, Germany) using the 488 $\mathrm{nm}$ line of an argon laser. Cell were contained in a temperature-controlled box (PeCon, Erbach, Germany) stabilized at $37^{\circ} \mathrm{C}$. Time-lapse sequences were collected using Nomarski differential interference microscopy, every 3 min for 72 h, using Leica confocal software (v. 2.61).

\subsection{Assignment of senescence-like growth arrest}

Senescence-like growth arrest was determined using two complementary criteria. Cell cycle analysis of cells by cytometry was used to detect elevated forward and site scatters, which reflect increased cell size and granularity, [35] and the presence of senescence-associated $\beta$-Gal staining at pH 6.0 (SA- $\beta-G a 1+$ cells) [36] was observed by phase-contrast microscopy.

\subsection{Western analysis of protein levels}

Protein was extracted from doxorubicin-treated and control cells as described elsewhere [21]. Total protein was quantified by the Bradford assay (Bio-Rad, Hercules, CA). About $30 \mu \mathrm{g}$ of denatured proteins was subjected to electrophoresis on SDS-polyacrylamide gels, blotted onto Optitran BA-S85 membranes (Schleicher \& Schuell, Dassel, Germany), probed with the specific antibodies — p53 (Santa Cruz, Quimigen, Spain), p21 ${ }^{\text {WAF1 }}$ (Calbiochem, Merck, Madrid, Spain), cyclin B1 (Santa Cruz), cyclin D1 (Santa Cruz), Mos (Santa Cruz) and $\alpha$-actin (Sigma) used as a normalization control—, incubated with secondary antibodies (Jackson ImmunoResearch), and detected by chemiluminescence using Luminol (Sigma).

\subsection{Clonogenic assay}




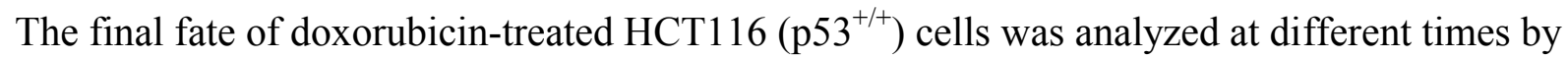
using a clonogenic assay, according to a protocol described elsewhere [37], with minor modifications that included using 5\% Giemsa (Sigma) for cell staining.

\section{Results}

\subsection{Transient senescence in HCT116 colon carcinoma cells treated with doxorubicin} We have analyzed the effects of nanomolar concentrations of doxorubicin on HCT116 cells bearing wild type $p 53$. Treatment with $125 \mathrm{nM}$ doxorubicin for $72 \mathrm{~h}$ (equivalent to its $\mathrm{IC}_{50}$ ) followed by either incubation in free-drug medium after withdrawal of the drug, or a continuous treatment with the drug for more than 13 days produced similar effects on cell distribution in the various phases of the cell cycle (Fig. 1A). Between 24 and $72 \mathrm{~h}$ treatments about half of the cell population was halted in G2/M and underwent senescence (see below). One day after withdrawal of the drug, some HCT116 cells were polyploid $(\mathrm{N}>4)$. A similar effect was observed after 4-days continuous treatment (cf. left and right panels in Fig. 1A). Timedependent monitoring of the fate of these cells showed they were distributed like in Fig. 1A (72h +10 days), which may be ascribed to the recovery of cell cycle distribution after treatment. According to cell staining with Trypan blue, about $20 \%$ cells, either in the floating or adhered population, were dying throughout the experimental analysis. The presence of polyploid cells was more evident during continuous treatments (Fig. 1A, right panel) and there was a shift of the peaks corresponding theoretically to G1 and G2 distribution, which may indicate that cells arrested in these phases were not the canonical $2 \mathrm{~N}$ and $4 \mathrm{~N}$ cells, but cells with some degree of polyploidization.

Figure 1B shows cytofluorimetric dot plots of the forward versus side scatter parameter. The relatively high values revealed the presence of senescence among the cells treated with doxorubicin for the first $72 \mathrm{~h}$, but not afterwards. The presence of senescent cells was confirmed by the specific lysosomal $\beta$-gal staining of senescent cells, at $\mathrm{pH} 6$, upon treatment with doxorubicin (Fig. 1C). Senescence was not observed after 72-h treatment irrespective of whether cells were maintained under continuous treatment with doxorubicin, or they were allowed to grow in fresh drug-free medium after withdrawal of the drug. This was understood to indicate they were re-entering the cell cycle (see Fig. 1A).

\subsection{Endoreduplication rather than mitosis generated giant multinucleate cells}

Having established the presence of a transient senescence-like arrest in doxorubicin-treated cells, we next sought to discern whether cells transiently arrested in G1 were entering the Sphase, in which DNA synthesis took place (measured by BrdU incorporation), and whether 
those in G2 phase were entering mitosis. To this end, cells treated with doxorubicin were tested for the presence of H3pser10, a histone variant only expressed during mitosis, by using a specific antibody, thus to substantiate that the cells that were synthesizing DNA did not enter several rounds of mitosis, but they were underwent endoreduplication (Fig. 2). Up to about 48-h treatments, DNA synthesis was active from both G1 and G2-like aneuploid cells, and also in cells with a $>4 \mathrm{~N}$ content (Fig. 2), regardless of whether they were allowed to grow in fresh medium after withdrawal of the drug, or they were under continuous drug treatment. However, after longer treatments with doxorubicin, DNA synthesis was inhibited. The presence of changes in the levels of several proteins that might participate in cell arrest in G1 and G2 will be considered in a following paragraph. Furthermore, at no time did mitosis increase compared to control cells (Fig. 2). Nevertheless, it is noteworthy that after 7 days under continuous treatment with doxorubicin a few endopolyploid cells had entered mitosis (bottom-right panel in Fig. 2).

\subsection{Nuclear budding in drug-treated cells is related to de-polyploidization and cell recovery} Under the microscope, doxorubicin-treated HCT116 (p53 $\left.3^{+/+}\right)$cells were large and contained more than one nucleus (Fig. 3B). Moreover, there was a time-dependent increase in the presence of peri-nuclear buds in all the cells — some of which are indicated by arrows in several panels of Fig. 3-. Sometimes, they covered almost the entire cytoplasm (Fig. 3F). These "bubble-like" cytoplasmic structures were not lysosomes since they stained negatively with Lysotracker (Molecular Probes) (not shown) but nuclear buds. After 8-days continuous treatment, the morphology of some surviving cells was similar to that of untreated HCT116 cells in respect to cell size, although they tended to grow in clusters (Fig. 3G). In addition, some living cells were unattached (floating), as judged by the absence of Trypan blue staining in this population (cf. panels A and H in Fig. 3). This observation indicated that some of the cells recovered after treatment or, alternatively, that budding nuclei may result in the generation of daughter cells that were released to the media. Such cells may hypothetically be Raju cells, so they may possess stem cell properties [26].

Therefore, we examined whether the "bubble-like" structures surrounding the cell nuclei, which sometimes covered almost the whole cell cytoplasm (Fig. 3F), were due to budding, and whether these structures contained genetic material. A time-lapse video analysis of drug-treated cells that documents that nuclear budding was a dynamic process. This is presented as supplementary information (Supplementary movie 1). In this video, budding progression can be observed as "bubbles" moving away from the nucleus.

We next examined whether budding removed the excess of DNA in cells overcoming senescence or mitotic catastrophe, or it was a step towards the formation of aneuploid cells with 
potential survival capacity. An additional problem with the second possibility is how these aneuploid nuclei can obtain enough cytoplasm organelles components to become Raju cells. Figure 4A shows the presence of giant doxorubicin-treated cells containing four macronuclei, which stained with DAPI, while Fig. 4B shows the staining of multinucleated cells (upper part of the panel), which can contain a macronucleus surrounded by some small micronuclei. As mentioned above, the micronuclei and some of the buds that might be produced via budding in the vicinity of the larger nuclei contained DNA, as indicated by their staining with DAPI (indicated by arrows in Figs. 4B and 4C), while, in other cases, they did not appear to contain any nucleic acid (Fig. 4D). Both the presence/absence of DNA, and the peri-nuclear location of the emerging buds were confirmed by time-lapse video microscopy using the fluorescent Draq5 dye, which can detect smaller quantities of DNA (Fig. 4F). Figures 4E and 4F show photograms taken from the time-lapse video, which allowed us to compare the bright field image of a doxorubicin-treated cell (panel E) alongside the same cell stained with Draq5 (panel F). DNA was labeled in both the nucleus and most of the peri-nuclear buds. A complete time-lapse video is shown as Supplementary movie 2.

\subsection{Several changes in protein levels concur with endoreduplication and nuclear budding} Time-dependent changes in $\mathrm{p} 53, \mathrm{p} 21^{\mathrm{WAF}}$, cyclin D1, cyclin B1 and Mos protein levels after treatment with doxorubicin are shown in Fig. 5. While $\mathrm{p} 21^{\mathrm{WAF} 1}$ levels increased upon treatment and remained high and they did not change in 3 days treatment, the level of p53 increased slightly in control (untreated cell) after $48 \mathrm{~h}$ treatment, while they remained low in drug-treated cells.

Cyclin B1 levels decreased upon treatment, and only about 19\% remained after removal of the drug followed by cell growing in drug-free medium, while about $21 \%$ remained after 7 -days continuous treatment. This decrease in cyclin B1 levels may be related to the absence of mitosis and the observed increase in polyploidization [38]. Deregulation of cyclin B1 may be mediated by changes in $\mathrm{p} 53$ protein levels, which is a post-transcriptional regulator of cyclin B1[38]. In the absence of regulation by $\mathrm{p} 53, \mathrm{p} 21^{\mathrm{WAF} 1}$ remained high (Fig. 5) after treatment and throughout the budding process. Levels of cyclin D, which is mostly associated to G1 phase, increased (Fig. 5), which may indicate that cells recovering after treatment may be entering a G1-like phase before re-cycling. The levels of Mos increased after treatment, which indicates that cells "leaving" a senescence state were sensed for they high DNA content. These results suggest that nuclear budding is to some extent controlled genetically. In line with the changes observed in protein levels, polyploid cells could arise as a consequence of DNA synthesis in the absence of 
mitosis, which could be the consequence of the inhibition of mitosis-associated proteins by $\mathrm{p} 21^{\mathrm{WAF} 1}[3]$.

\subsection{After nuclear budding some cells recover, proliferate and they might grow to be multidrug- resistant cells}

As described above, most of the doxorubicin-treated cells remained alive after the budding procedure (Fig. $3 \mathrm{G}-\mathrm{H}$ ). A clonogenic assay was performed by seeding cells at different time intervals during the treatments (Fig. 6A). After $72 \mathrm{~h}$ continuous treatments colonies ( $\geq 50$ cells) were not observed in concordance with these cells were senescent (Fig. 1 B-C). After budding, the generated cells proliferated, although with different efficiencies that depended on whether they grew in the absence or presence of the drug (Fig. 6A).

Both adherent and floating cells were harvested at the times in which proliferation was observed during the clonogenic assays, plated in fresh drug-free medium, and allowed to grow for additional $24 \mathrm{~h}$. Afterwards, six antitumor drugs with different mechanisms of action (doxorubicin, WP631, etoposide (VP-16), camptothecin, paclitaxel and cisplatin) were incubated with such cells for $72 \mathrm{~h}$, and their survival was measured by the MTT method (Fig. 6B). Only continuous treatment with several of these drugs disclosed a significant increase of drug-resistant cells (Student's t-test, Fig. 6B). This outcome was not seen when cells were allowed to grow in fresh drug-free medium after withdrawal of the drugs (Fig. 6B). The anthracyclines (doxorubicin and WP631), of which the former is considered a topoisomerase II poison, like etoposide (VP16), are among the drugs to which the HCT116 became less sensitive. After budding, cells were also less sensitive to paclitaxel, a mitotic inhibitor. On the other hand, cells growing after budding were neither more resistant to the topoisomerase I inhibitor camptothecin nor to the DNA-alkylating agent cisplatin (Fig. 6B).

These results indicate that surviving cells were susceptible to a variety of drugs, and resistant cells only arose following the previous treatment with nanomolar concentrations of doxorubicin when the contact with the new drugs was continuous. This cell behavior may be independent of whether the cells arose from the micronuclei shown in Figs. 3 and 4, or as the results of nuclear budding, which tentatively would generate daughter cells more resistant to antitumor drugs.

\section{Discussion}

The relevance of senescence and non-apoptotic routes to cell death has been overshadowed by the high interest in apoptosis. Evidence is accumulating that senescence may play a key role in chemotherapy outcome $[3,12,22]$. Low doses of doxorubicin are a well-known inductor of 
senescence in HCT116 cells containing wild-type 53 [3, 12]. Both senescence and mitotic catastrophe may result in the presence of giant multinuclate cells. Genetic destabilization can be produced when they re-enter the cell cycle after a prolonged $\mathrm{p} 21^{\mathrm{WAF} 1}$ induction [3]. Here, we have shown that endopolyploidization occurs in the presence of DNA synthesis (Fig. 2) without cells entering mitosis, so giant cells can emerge from G1-like or G2-like aneuploid cells. These results are in agreement with a recent report that indicates that induction of senescence by doxorubicin leads to increased genomic instability in HCT116 cells [39]. After treatments with low nanomolar concentrations of doxorubicin, $\mathrm{p} 21^{\mathrm{WAF} 1}$ levels were higher than in control cells, an enhancement that was observable from $24 \mathrm{~h}$ onwards (Fig. 5). In fact, there was overexpression of $\mathrm{p} 21^{\mathrm{WAF} 1}$ throughout all the budding process, which is consistent with the role of this protein in the development of polyploidy $[3,40]$ and its role of this protein in protecting cells against doxorubicin-induced mitotic catastrophe [41]. Accordingly, p2 ${ }^{\mathrm{WAF} 1}$-mediated depletion of some checkpoint control proteins may result in endoreduplication (Fig. 5 and ref.[3]), while $\mathrm{p} 21^{\mathrm{WAF} 1}$ also maintained the halt in $\mathrm{G} 2$ in absence of cells entering mitosis, even though p53 levels decreased during long treatments. The levels of Mos, a protein involved in the control of meiosis [42], were enhanced, which would indicate the presence of some type of control of the budding process, in agreement with the synergy that has described between the Mos/mitogen-activated protein kinase pathway and the loss of p53 function in the occurrence of chromosome instability[43]; in our case a time-dependent decrease in p53 levels (Fig. 5). The increase in Mos levels occurred in parallel to the decrease in p53 (Fig. 5), which is coherent with the previously observed Mos increase observed in $\mathrm{p} 53^{-/-}$cells [43].

At first glance, the observation of multinucleated giant cells in absence of mitosis and in the presence of DNA synthesis (Fig. 2) is at variance with previous observations of the behavior of cells treated with low concentrations of doxorubicin, which cells entered mitosis and showed abnormal mitotic figures. We did not observe a release from $\mathrm{p} 21^{\mathrm{WAF} 1}$-mediated growth arrest upon drug-treatment, which may explain why cells did not enter mitosis and mitotic catastrophe [44]. Induction of $\mathrm{p} 21^{\mathrm{WAF} 1}$ in cells containing wild-type p53 may result in genetic destabilization $[3,45]$. However, the $\mathrm{p} 21^{\mathrm{WAF} 1}$ levels did not maintain growth arrest and senescence; tentatively because of the changes in other protein levels (Fig. 5). The $\mathrm{p} 21^{\mathrm{WAF} 1}$ induction was, in this case, observed while p53 was down-regulated, which indicates that the formation of endopolyploid cells might be not an exclusive characteristic of cells lacking wild-type p53, but it can be induced by low doses of some antitumor agents in $\mathrm{p} 53^{+/+}$cells.

The production of buds was sometimes so intense that cells appear to be filled by "bubblelike" structures (Fig. 3F). A mode of cell division that may be related to budding has been 
described and referred to as neosis, which is defined as a parasexual reduction division resulting in polyploid-multinucleate cells [30]. According to this novel mode of cell division, budding nuclei would distribute genetic material to small daughter cells. Such small aneuploid cells (Raju cells) may have an extended life span and be multidrug-resistant tumor cells [26]. Although our results show that at the end of a prolonged treatment some cells can recover (Fig. $3 \mathrm{G}$ and $\mathrm{H}$ ), the budding process did not provide evidence as to whether the small buds leaving the nuclei were Raju-like cells. An additional problem in considering the possibility that the buds may generate actual Raju daughter cells is our lack of understanding of how the buds could acquire the minimum cell organelles needed for them to be considered as potential stem cells. Time-lapse videos, shown as supplementary material, indicated that cytoplasm was not included during the budding process. We favor an alternative explanation based on the idea that a portion of the cell population might escape death through de-polyploidization. This could mean that some "extra DNA" was extruded from the nuclei via budding. Cells would thus bear more acceptable level of aneuploidy/polyploidy. This would be concordant with reports that some inhibitors of replication increase micronucleation and formation of buds containing autonomous replicating extrachromosomal structures that are lost spontaneously in absence of selection [32]. Some buds were stained with the DNA-binding dyes DAPI or Draq5 (Fig. 4). They could contain chromosome fragments, which are difficult to envisage as potential independent cells. We conclude that cells recovering after budding were some of the former large aneuploid cells rather than 'new' cells produced by neosis. An enhancement in the levels of the meiosis-related protein Mos was observed, which agrees with the view that cells somehow detect the presence of extra DNA (as it occurs during the first meiotic division [42]).

As mentioned above, what is peculiar in the present study is that a nuclear budding procedure might reduce the polyploidy of giant cells bearing wild-type p53 protein, the levels of which were reduced by drug treatment. In contrast, a significant proportion of the buds leaving the nuclei in doxorubicin-treated cells did not contain DNA. This experimental observation would agree with a somewhat stochastic liberation of material, yet the presence of meiotic genes suggests that some sort of control could exist. These observations are reminiscent of a selective elimination of extrachromosomal 'double minutes' by replication inhibitors [33].

A clonogenic assay (Fig. 6A) showed that after the budding process most of the surviving HCT116 cells proliferated for a long time, yet they displayed different degrees of susceptibility to a variety of drugs (Fig. 6B). Cells that recovered from the initial treatment were significantly more resistant to several antitumor drugs when they were incubated continuously for 33 days. 
Conversely, when those cells were allowed to recover in fresh drug-free medium after withdrawal of the drug they were drug sensitive (Fig. 6).

One known role of p53 is to avert aneuploidy by blocking endoreduplication. Low nanomolar concentrations of doxorubicin produced a transient increment in p53 levels, which was followed by a reduction of p53, compared to untreated cells (Fig. 5). This might occur through a direct effect of doxorubicin on gene transcription $[22,46]$. The enhancement of $\mathrm{p} 21^{\mathrm{WAF} 1}$ levels in tumor cells during chemotherapy has been considered to contribute to carcinogenesis and tumor progression, as a consequence of genetic destabilization [40], but also to the growth arrest during senescence $[3,10]$. The results presented here point out that increased ploidy, which is also associated with $\mathrm{p} 21^{\mathrm{WAF} 1}$, does not necessarily lead to more invasive cells. Although not yet directly proven, our observations suggest that nuclear budding does not generate Raju cells — which are deemed to be rather tumorogenic [26]—, nor does it improve the life span of the cell. Additional elucidations of the mechanisms that control endoreduplication should provide a more complete understanding of cell death and resistance to antitumor agents. In this context, it is remarkable that cells that survived the primary treatment with moderate concentrations of doxorubicin only developed drug resistance when they were maintained under continuous contact with a selecting drug (Fig. 6B), an observation with potential clinical relevance that will merit further consideration.

\section{Acknowledgements}

We thank Dr. Lidia Bardia for confocal microscopy support and advice. Supported by grants from the former Spanish Ministry of Education and Science: BFU2007-60998, and the FEDER program of the European Community. M.B. is recipient of a fellowship from the 'Parc Cientific de Barcelona-CSIC'.

\section{REFERENCES}

[1] Suijkerbuijk SJ, Kops GJ. Preventing aneuploidy: The contribution of mitotic checkpoint proteins. Biochim Biophys Acta 2008;1786:24-31.

[2] Wang X, Cheung HW, Chun AC, Jin DY, Wong YC. Mitotic checkpoint defects in human cancers and their implications to chemotherapy. Front Biosci 2008;13:2103-14.

[3] Chang BD, Broude EV, Fang J, Kalinichenko TV, Abdryashitov R, Poole JC, et al. $\mathrm{p} 21^{\mathrm{Waf} 1 / \mathrm{Cip} 1 / \mathrm{Sdi1}}$-induced growth arrest is associated with depletion of mitosis-control proteins and leads to abnormal mitosis and endoreduplication in recovering cells. Oncogene 2000;19:2165-70. 
[4] Murray AW. Recycling the cell cycle: cyclins revisited. Cell 2004;116:221-34.

[5] Weaver BA, Cleveland DW. Decoding the links between mitosis, cancer, and chemotherapy: The mitotic checkpoint, adaptation, and cell death. Cancer Cell 2005;8:712.

[6] Castedo M, Perfettini JL, Roumier T, Valent A, Raslova H, Yakushijin K, et al. Mitotic catastrophe constitutes a special case of apoptosis whose suppression entails aneuploidy. Oncogene 2004;23:4362-70.

[7] Mansilla S, Priebe W, Portugal J. Mitotic catastrophe results in cell death by caspasedependent and caspase-independent mechanisms. Cell Cycle 2006;5:53-60.

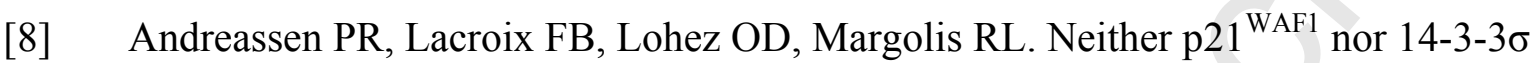
prevents G2 progression to mitotic catastrophe in human colon carcinoma cells after DNA damage, but $\mathrm{p} 21^{\mathrm{WAF} 1}$ induces stable $\mathrm{G} 1$ arrest in resulting tetraploid cells. Cancer Res 2001;61:7660-8.

[9] Ferbeyre G, de Stanchina E, Lin AW, Querido E, McCurrach ME, Hannon GJ, et al. Oncogenic ras and p53 cooperate to induce cellular senescence. Mol Cell Biol 2002;22:3497-508.

[10] Roninson IB. Tumor cell senescence in cancer treatment. Cancer Res 2003;63:2705-15.

[11] Chang BD, Xuan Y, Broude EV, Zhu H, Schott B, Fang J, et al. Role of p53 and p2 $1^{\text {wafl/cip1 }}$ in senescence-like terminal proliferation arrest induced in human tumor cells by chemotherapeutic drugs. Oncogene 1999;18:4808-18.

[12] Gewirtz DA, Holt SE, Elmore LW. Accelerated senescence: an emerging role in tumor cell response to chemotherapy and radiation. Biochem Pharmacol 2008;76:947-57.

[13] Roninson IB, Broude EV, Chang B-D. If not apoptosis, then what? Treatment-induced senescence and mitotic catastrophe in tumor cells. Drug Resist Updat 2001;4:303-13.

[14] Mansilla S, Bataller M, Portugal J. Mitotic catastrophe as a consequence of chemotherapy. Anticancer Agents Med Chem 2006;6:589-602.

[15] Eom YW, Kim MA, Park SS, Goo MJ, Kwon HJ, Sohn S, et al. Two distinct modes of cell death induced by doxorubicin: apoptosis and cell death through mitotic catastrophe accompanied by senescence-like phenotype. Oncogene 2005;24:4765-77.

[16] Hyzy M, Bozko P, Konopa J, Skladanowski A. Antitumour imidazoacridone C-1311 induces cell death by mitotic catastrophe in human colon carcinoma cells. Biochem Pharmacol 2005;69:801-9. 
[17] Vakifahmetoglu H, Olsson M, Tamm C, Heidari N, Orrenius S, Zhivotovsky B. DNA damage induces two distinct modes of cell death in ovarian carcinomas. Cell Death Differ 2008;15:555-66.

[18] Lock RB, Stribinskiene L. Dual modes of death induced by etoposide in human epithelial tumor cells allow Bcl-2 to inhibit apoptosis without affecting clonogenic survival. Cancer Res 1996;56:4006-12.

[19] Niida H, Katsuno Y, Banerjee B, Hande MP, Nakanishi M. Specific role of Chk1 phosphorylations in cell survival and checkpoint activation. Mol Cell Biol 2007;27:257281.

[20] Ianzini F, Mackey M. Mitotic Catastrophe. In: Gewirtz DA, Holt SE, Grant S, editors. Apoptosis, Senescence and Cancer. New Jersey: Humana Press, 2007. p. 73-91.

[21] Bataller M, Méndez C, Salas JA, Portugal J. Mithramycin SK modulates polyploidy and cell death in colon carcinoma cells. Mol Cancer Ther 2008;7:2988-97.

[22] Chang BD, Swift ME, Shen M, Fang J, Broude EV, Roninson IB. Molecular determinants of terminal growth arrest induced in tumor cells by a chemotherapeutic agent. Proc Natl Acad Sci USA 2002;99:389-94.

[23] Castedo M, Perfettini JL, Roumier T, Andreau K, Medema R, Kroemer G. Cell death by mitotic catastrophe: a molecular definition. Oncogene 2004;23:2825-37.

[24] Demidenko ZN, Kalurupalle S, Hanko C, Lim CU, Broude E, Blagosklonny MV. Mechanism of G1-like arrest by low concentrations of paclitaxel: next cell cycle p53dependent arrest with sub G1 DNA content mediated by prolonged mitosis. Oncogene 2008;27:4402-10.

[25] Blagosklonny MV. Mitotic arrest and cell fate: why and how mitotic inhibition of transcription drives mutually exclusive events. Cell Cycle 2007;6:70-4.

[26] Rajaraman R, Guernsey DL, Rajaraman MM, Rajaraman SR. Stem cells, senescence, neosis and self-renewal in cancer. Cancer Cell Int 2006;6:25.

[27] Erenpreisa J, Ivanov A, Wheatley SP, Kosmacek EA, Ianzini F, Anisimov AP, et al. Endopolyploidy in irradiated p53-deficient tumour cell lines: Persistence of cell division activity in giant cells expressing Aurora-B kinase. Cell Biol Int 2008;32:1044-56.

[28] Ivanov A, Cragg MS, Erenpreisa J, Emzinsh D, Lukman H, Illidge TM. Endopolyploid cells produced after severe genotoxic damage have the potential to repair DNA double strand breaks. J Cell Sci 2003;116:4095-106. 
[29] Ullah Z, Kohn MJ, Yagi R, Vassilev LT, DePamphilis ML. Differentiation of trophoblast stem cells into giant cells is triggered by $\mathrm{p} 57 / \mathrm{Kip} 2$ inhibition of CDK1 activity. Genes Dev 2008;22:3024-36.

[30] Sundaram M, Guernsey DL, Rajaraman MM, Rajaraman R. Neosis: a novel type of cell division in cancer. Cancer Biol Ther 2004;3:207-18.

[31] Erenpreisa J, Kalejs M, Ianzini F, Kosmacek EA, Mackey MA, Emzinsh D, et al. Segregation of genomes in polyploid tumour cells following mitotic catastrophe. Cell Biol Int 2005;29:1005-11.

[32] Shimizu N, Itoh N, Utiyama H, Wahl GM. Selective entrapment of extrachromosomally amplified DNA by nuclear budding and micronucleation during S phase. J Cell Biol 1998;140:1307-20.

[33] Shimizu N, Misaka N, Utani K. Nonselective DNA damage induced by a replication inhibitor results in the selective elimination of extrachromosomal double minutes from human cancer cells. Genes Chromosomes Cancer 2007;46:865-74.

[34] Villamarín S, Mansilla S, Ferrer-Miralles N, Priebe W, Portugal J. A comparative analysis of the time-dependent antiproliferative effects of daunorubicin and WP631. Eur J Biochem 2003;270:764-70.

[35] Biroccio A, Amodei S, Antonelli A, Benassi B, Zupi G. Inhibition of c-Myc oncoprotein limits the growth of human melanoma cells by inducing cellular crisis. J Biol Chem 2003;278:35693-701.

[36] Dimri GP, Lee X, Basile G, Acosta M, Scott G, Roskelley C, et al. A biomarker that identifies senescent human cells in culture and in aging skin in vivo. Proc Natl Acad Sci USA 1995;92:9363-7.

[37] Plumb JA. Cell sensitivity assays: clonogenic assay. Methods Mol Med 2004;88:159-64.

[38] Ianzini F, Bertoldo A, Kosmacek EA, Phillips SL, Mackey MA. Lack of p53 function promotes radiation-induced mitotic catastrophe in mouse embryonic fibroblast cells. Cancer Cell Int 2006;6:11.

[39] Sliwinska MA, Mosieniak G, Wolanin K, Babik A, Piwocka K, Magalska A, et al. Induction of senescence with doxorubicin leads to increased genomic instability of HCT116 cells. Mech Ageing Dev 2009;130:24-32.

[40] Niculescu AB, Chen X, Smeets M, Hengst L, Prives C, Reed SI. Effects of p2 $1^{(\mathrm{Cip} 1 / \text { Wafl) }}$ at both the G1/S and the G2/M cell cycle transitions: $p R b$ is a critical determinant in blocking DNA replication and in preventing endoreduplication. Mol Cell Biol 1998;18:629-43. 
[41] Lin YC, Wang FF. Mechanisms underlying the pro-survival pathway of p53 in suppressing mitotic death induced by adriamycin. Cell Signal 2008;20:258-67.

[42] Kalejs M, Ivanov A, Plakhins G, Cragg MS, Emzinsh D, Illidge TM, et al. Upregulation of meiosis-specific genes in lymphoma cell lines following genotoxic insult and induction of mitotic catastrophe. BMC Cancer 2006;6:6.

[43] Fukasawa K, Vande Woude GF. Synergy between the Mos/mitogen-activated protein kinase pathway and loss of p53 function in transformation and chromosome instability. Mol Cell Biol 1997;17:506-18.

[44] Bunz F, Dutriaux A, Lengauer C, Waldman T, Zhou S, Brown JP, et al. Requirement for p53 and p21 to sustain G2 arrest after DNA damage. Science 1998;282:1497-501.

[45] Broude EV, Demidenko ZN, Vivo C, Swift ME, Davis BM, Blagosklonny MV, et al. p21 (CDKN1A) is a negative regulator of p53 stability. Cell Cycle 2007;6:1468-71.

[46] Mansilla S, Portugal J. Sp1 transcription factor as a target for anthracyclines: Effects on gene transcription. Biochimie 2008;90:976-87. 


\section{LEGENDS TO FIGURES}

Fig. 1. (A) Flow cytometry analyses of HCT116 $\left(\mathrm{p} 53^{+/+}\right)$colon carcinoma cells treated with a 125 $\mathrm{nM}$ doxorubicin (equivalent to its $\mathrm{IC}_{50}$ ). The experiments displayed correspond to either $72 \mathrm{~h}$ incubation with the drug followed by incubation in fresh drug-free medium after withdrawal of the drug (left panel) or continuous treatments for the times stated (right panel). Although in drugtreated cells the different peaks are market as and $2 \mathrm{~N}$ or $4 \mathrm{~N}$ for the convenience of uniform plotting, they may contain a higher, aneuploid, DNA content (see main text for further details). (B) Detection of senescence-like arrest in doxorubicin-treated HCT116 cells by cytofluorimetric dot plots of forward (x-axis) versus side (y-axis) scatter parameters. High values of both parameters are observed after $48 \mathrm{~h}$ and $72 \mathrm{~h}$ treatments. (C) Microscopic analysis of SA- $\beta$-gal expression at $\mathrm{pH} 6$ (a subrogate marker of senescence) in doxorubicin-treated HCT116 cells for $48 \mathrm{~h}$ shows the presence of senescence.

Fig. 2. (A) Bromodeoxyuridine (BrdU) incorporation in the absence (control), or during treatment with $125 \mathrm{nM}$ doxorubicin, shows the presence of DNA synthesis (BrdU-positive cells) depending on the phase of the cell cycle (PI staining), which suggests cells were labeled in S phase and they underwent endoreduplication in the absence of mitosis (see panel (B)). (B) Assay for the simultaneous detection of diploid and polyploid cells by PI and cells in mitosis by an antibody against H3pS10 (specific marker Ser-10-phosphorylated histone H3). The percentage of mitotic cells was rather small, even though increased ploidy was evident, which indicates the presence of endoreduplication.

Fig. 3. Microscopic analysis of HCT116 $\left(\mathrm{p} 53^{+/+}\right)$cells treated with $125 \mathrm{nM}$ doxorubicin show the presence of giant cells with macronuclei and peri-nuclear "bubble" structures (indicated by arrows) formed by a budding process. (A) Untreated cells. (B, C and F) Cells treated for $72 \mathrm{~h}$, followed by incubation in fresh drug-free medium for additional 4 days, 7 days or 12 days respectively, or (D) Cells treated continuously during 6 days. Panels E and F show some examples of cells in which budding ended in "bubble-like" structures covering almost the entire cytoplasm. ( $\mathbf{G}$ and $\mathbf{H}$ ) Cells that recovered after treatment with doxorubicin were allowed to grow for 33 days in fresh drug-free medium after withdrawal of the drug. Panel G shows attached cells, while those in panel $\mathrm{H}$ are floating cells, which were alive according to their exclusion of Trypan blue (bars correspond to $50 \mu \mathrm{m}$ ). See also Fig. 4 and the two time-lapse videos shown as Supplementary material on line. 
Fig. 4. Morphological analysis of doxorubicin-treated HCT116 cells stained with the DNAbinding dyes DAPI or Draq5. (A) Cells treated with $125 \mathrm{nM}$ doxorubicin show macronuclei, which stained with DAPI. (B) Cells treated with $125 \mathrm{nM}$ doxorubicin for $72 \mathrm{~h}$ and allowed to grow in fresh drug-free medium for additional 4 days show the presence of peri-nuclear buds. (C and D) HCT116 cells treated continuously with doxorubicin for 72 days also show the presence of buds. The presence of buds in some cells is indicated by arrows, (bars correspond to $50 \mu \mathrm{m}$ ). (E) Bright-field photogram of a time-lapse microscopy analysis of HCT116 cells treated with 125 $\mathrm{nM}$ doxorubicin for $72 \mathrm{~h}$, allowed to grow in fresh drug-free medium during 3 days, and recorded afterwards. (F) Image of the cell shown in panel E stained with Draq5. Fluorescence is observed in the nucleus and inside most of the peri-nuclear budding structures. The complete time-lapse video is shown as Supplementary material on line.

Fig. 5. Western blot analysis of changes in protein levels in HCT116 $\left(\mathrm{p} 53^{+/+}\right)$treated with a low $(125 \mathrm{nM})$ doxorubicin concentration for the times indicated at the top of the figure. For the sake of comparison, the distribution of the cells in the different phases of the cell cycle is also displayed at the top. Lane a: control, untreated, cells, lanes b-d: protein levels after continuous treatment with $125 \mathrm{nM}$ doxorubicin, lanes e and f: cells treated with $125 \mathrm{nM}$ doxorubicin for $72 \mathrm{~h}$ were allowed to grow for additional 1 or 4 days in drug-free medium after withdrawal of the drug, lanes g and h: cells treated continuously with $125 \mathrm{nM}$ doxorubicin for 4 or 7 days respectively.

Fig. 6. Analysis of the fate of HCT116 $\left(\mathrm{p} 53^{+/+}\right)$cells recovering after treatment with doxorubicin. (A) Clonogenic assays showing the proliferation of HCT116 cells treated with $125 \mathrm{nM}$ doxorubicin for different periods of time. The times indicated at the top correspond to the moment at which doxorubicin-treated cells were re-seeded ( $1 \times 10^{3}$ cells in $60 \mathrm{~mm}$ Petri dishes). The clonogenic capacity was determined as the percentage of colonies containing $\geq 50$ cells, after a posterior incubation for the times indicated at the left side. After $72 \mathrm{~h}$ treatments there was no proliferation in keeping with the presence of senescence (see also, Figs. 1B and 1C). After 72-h treatments with doxorubicin followed by 30 days incubation in fresh drug-free medium: $21.0 \%$, 26.0 and $48.7 \%$ colonies were quantified after 10 days, compared to the control (100\%), while 33 days of continuos doxorubicin-treatment rendered 20.9, 27.0 and 56.6\% colonies respectively. (B) Analysis of the HCT116 cell proliferation using cells that survived to the treatment with moderate doses of doxorubicin. Cells recovering after treatment with doxorubicin for $72 \mathrm{~h}$ 
followed by 30-days incubation in fresh medium were re-seeded in new fresh drug-free medium for additional $24 \mathrm{~h}$ and treated with a variety drugs indicated in the x-axis. Alternatively, cells treated continuously for 33 days were incubated with the same drugs with different mechanisms of action: $125 \mathrm{nM}$ doxorubicin, $35 \mathrm{nM}$ WP631, $5 \mu \mathrm{M}$ etoposide (VP-16), $150 \mathrm{nM}$ camptothecin, $15 \mathrm{nM}$ paclitaxel or $30 \mu \mathrm{M}$ cisplatin. White bars correspond to untreated cells, light gray bars: recovering cells treated, with the drug concentrations indicated in the Fig., for $72 \mathrm{~h}$, followed by 30 days in fresh drug-free medium, dark gray bars: cells treated continuously for 33 days (means $\pm \mathrm{SD}$, from three experiments; the differences in the proliferation of treated versus untreated cells that were statistically significant are indicated $\left(* \mathrm{p}<0.05,{ }^{* *} \mathrm{p}<0.01\right.$, unpaired Student's-t test)). 

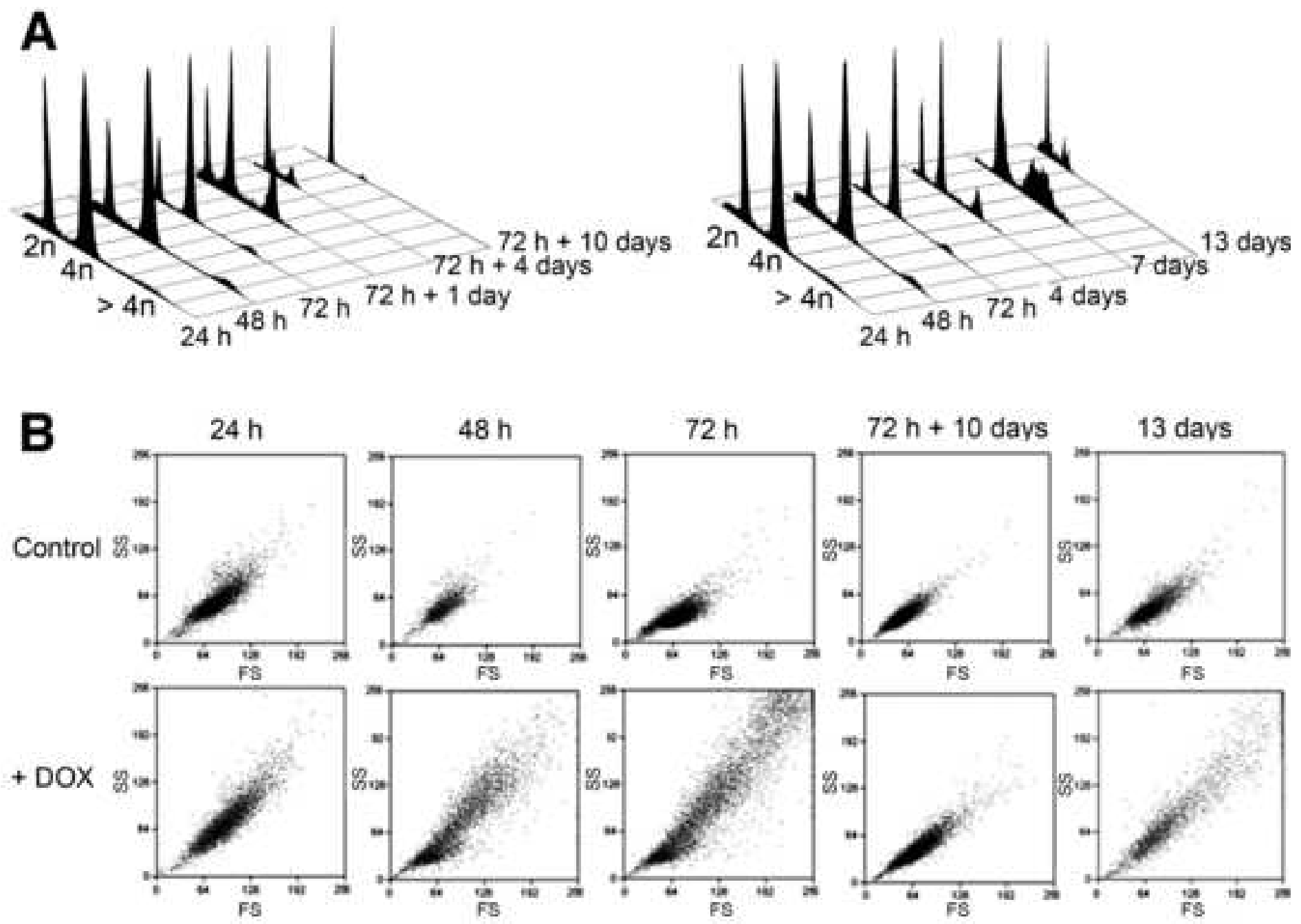

C
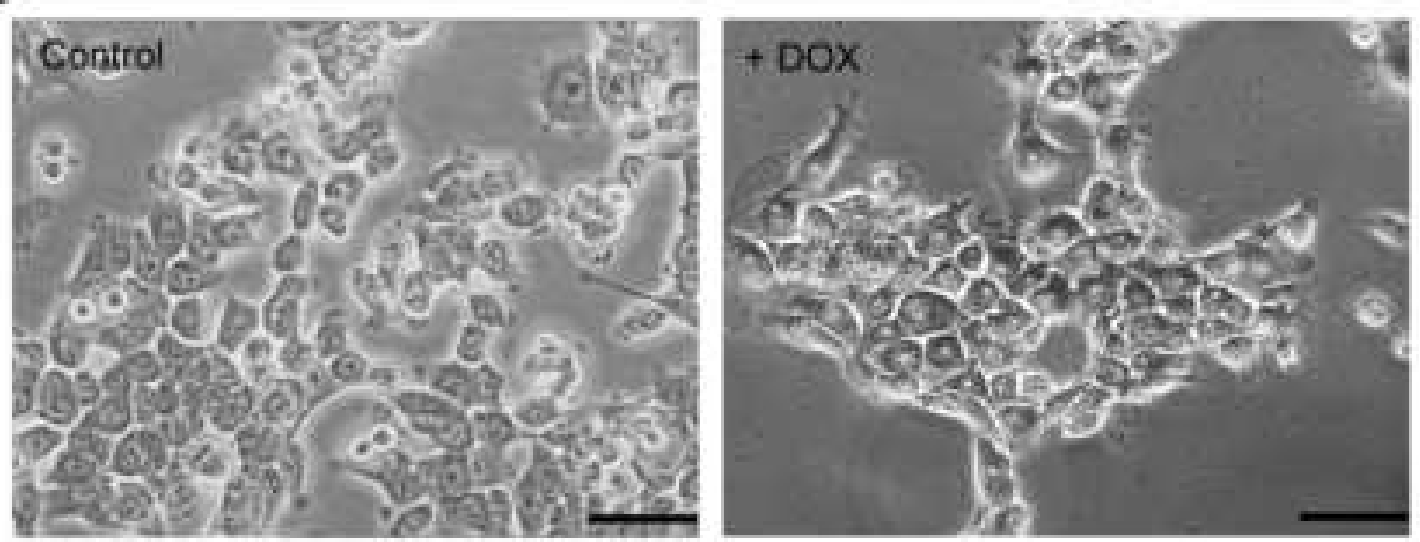

Figure 1 

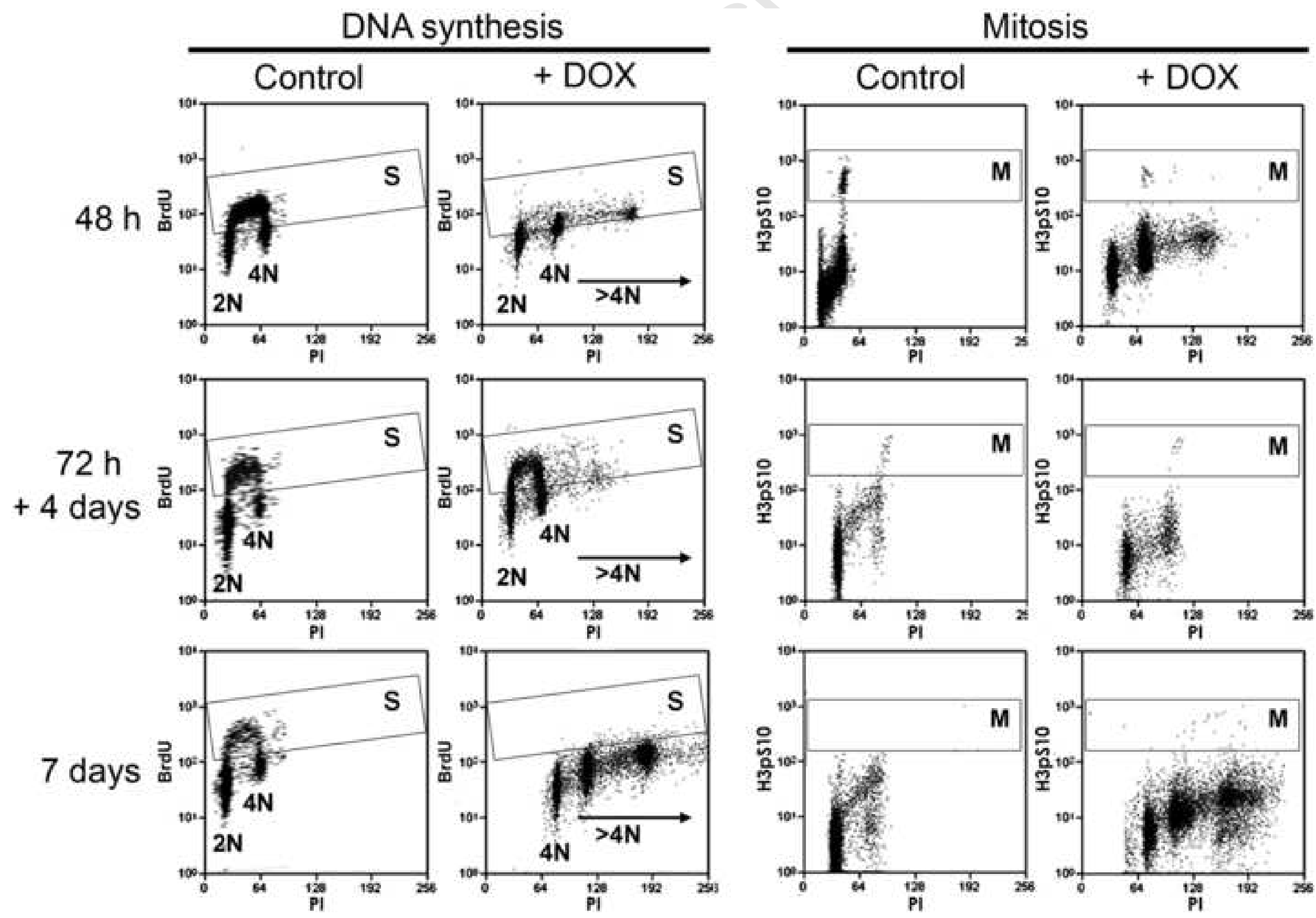

Figure 2 

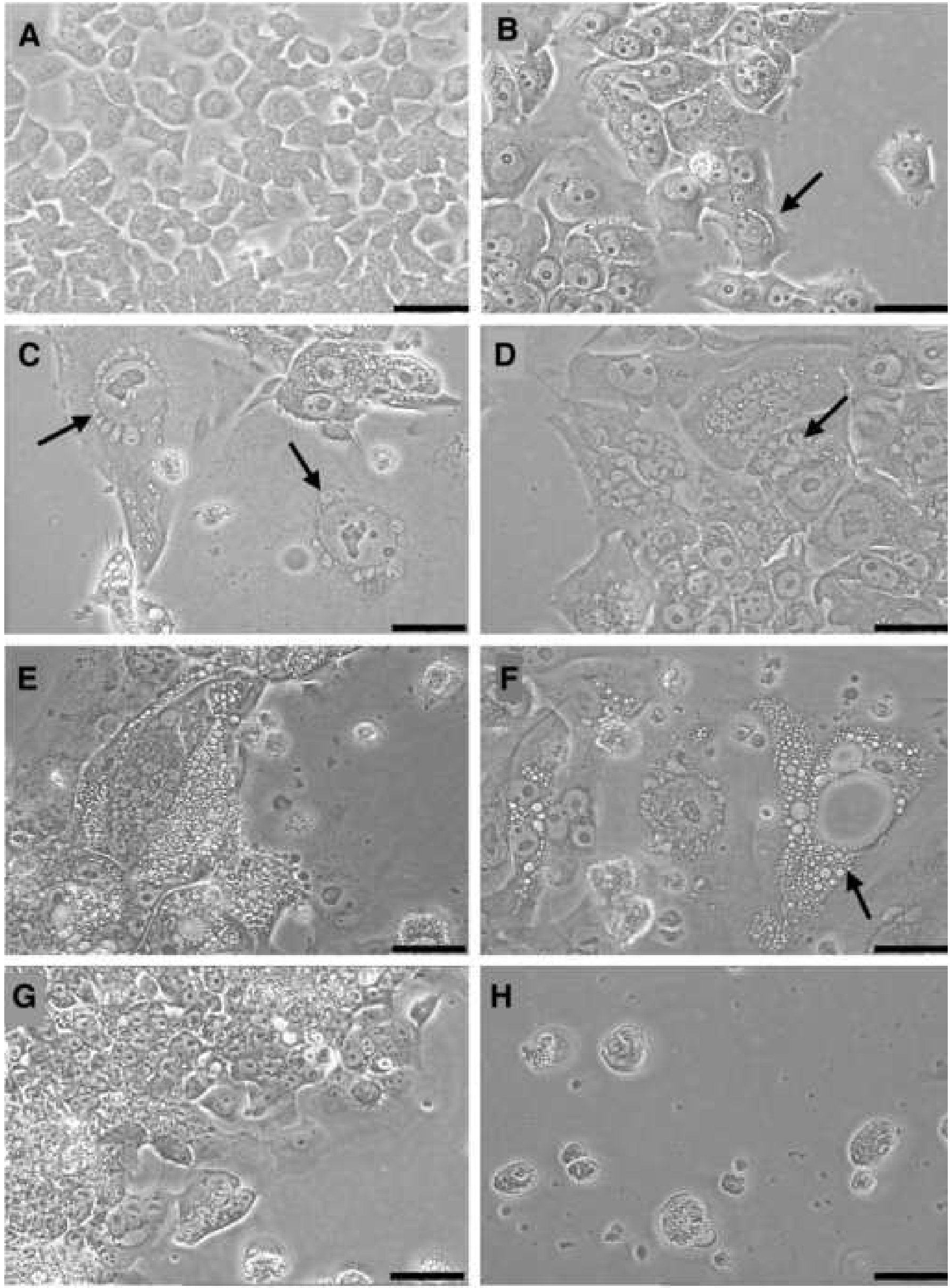

H

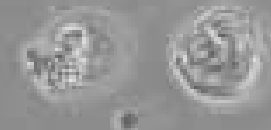

Figure 3 

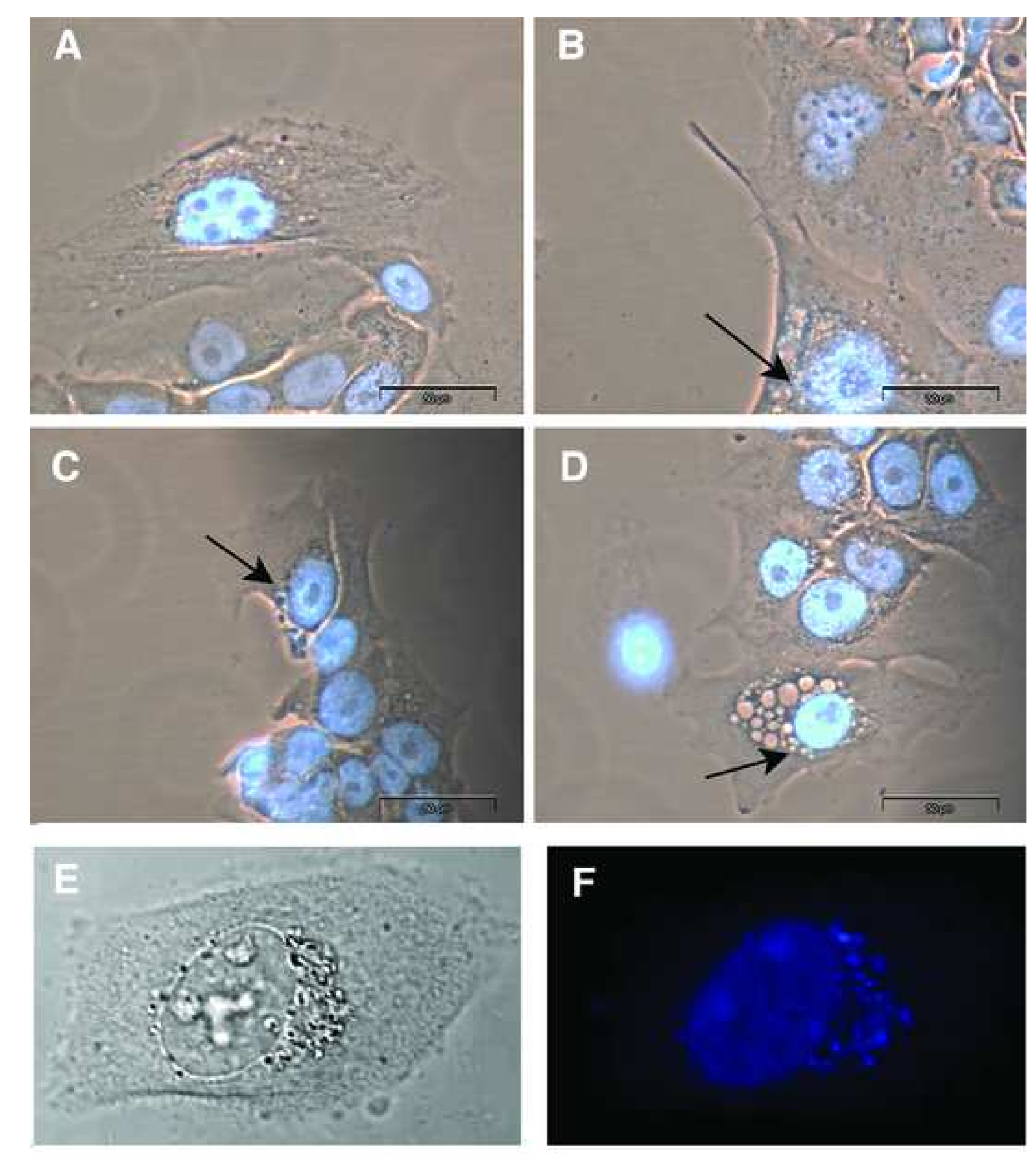

\section{Figure 4}

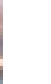
(1)
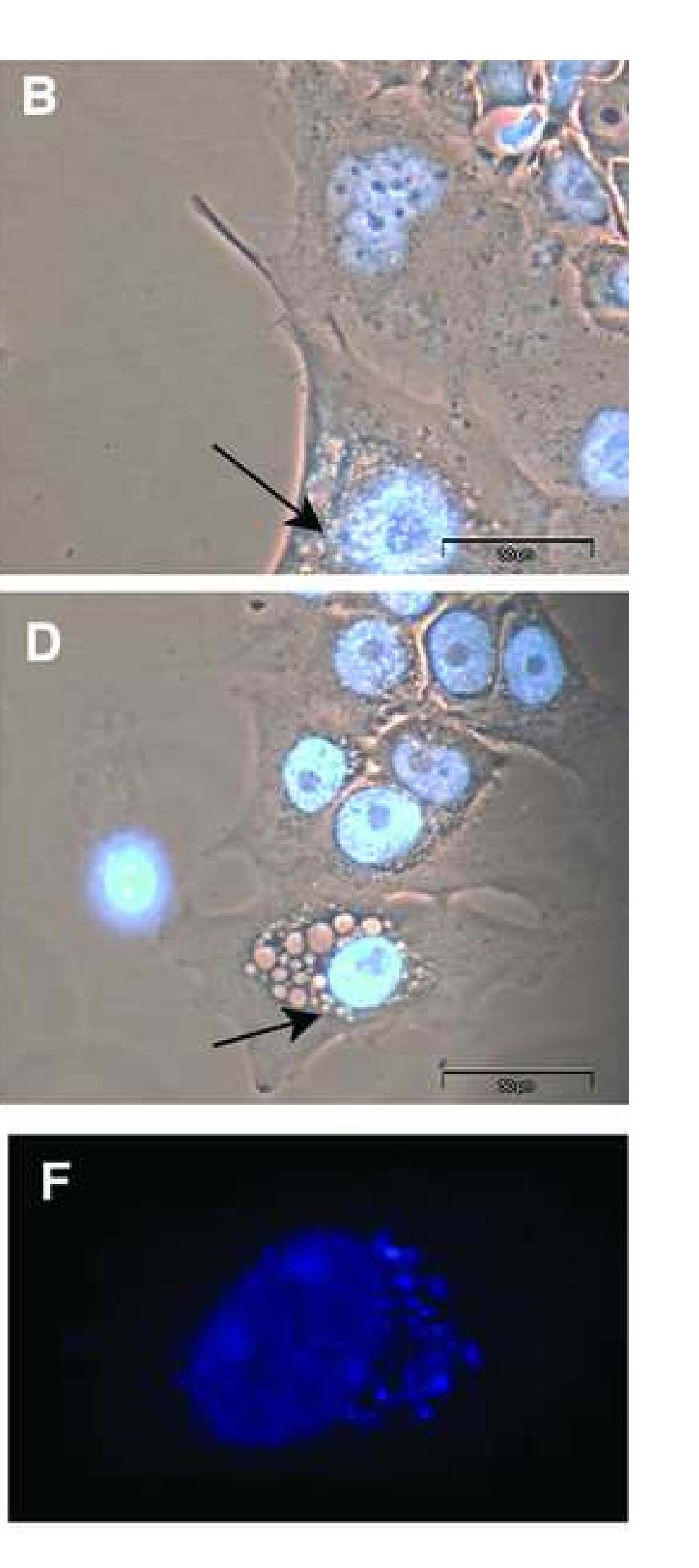

\section{(20)}

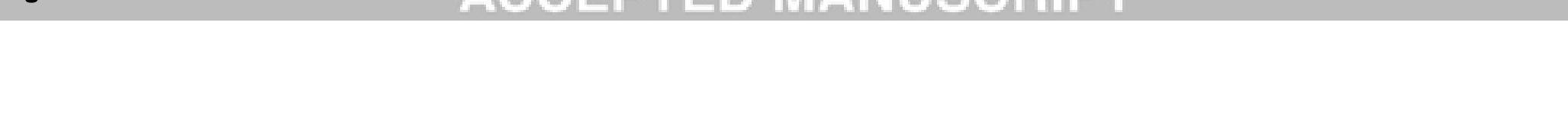



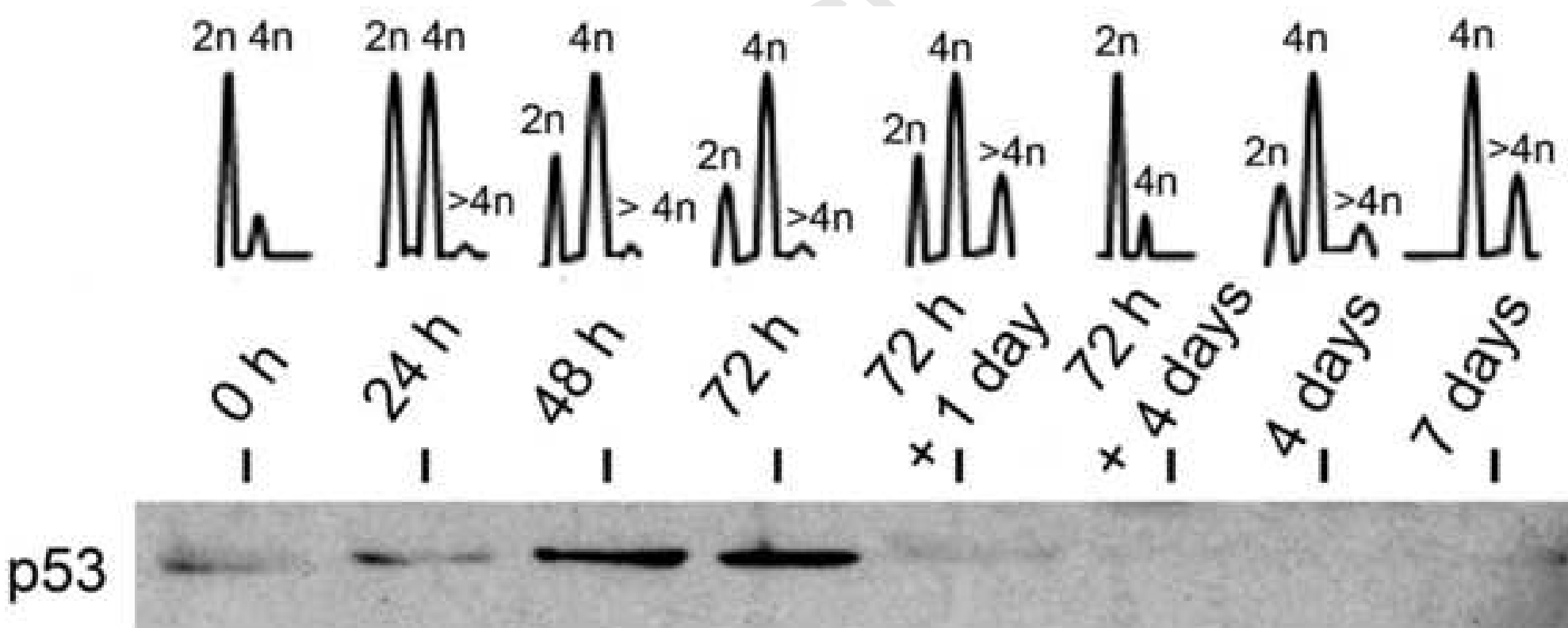

$$
\text { p21 WAF1 }
$$

Cyclin D1

Cyclin B1

Mos

$$
\alpha \text {-actin }
$$

$$
\text { a b }
$$

$$
\text { C }
$$

d

e

$$
\text { f }
$$

g

h

Figure 5 
A
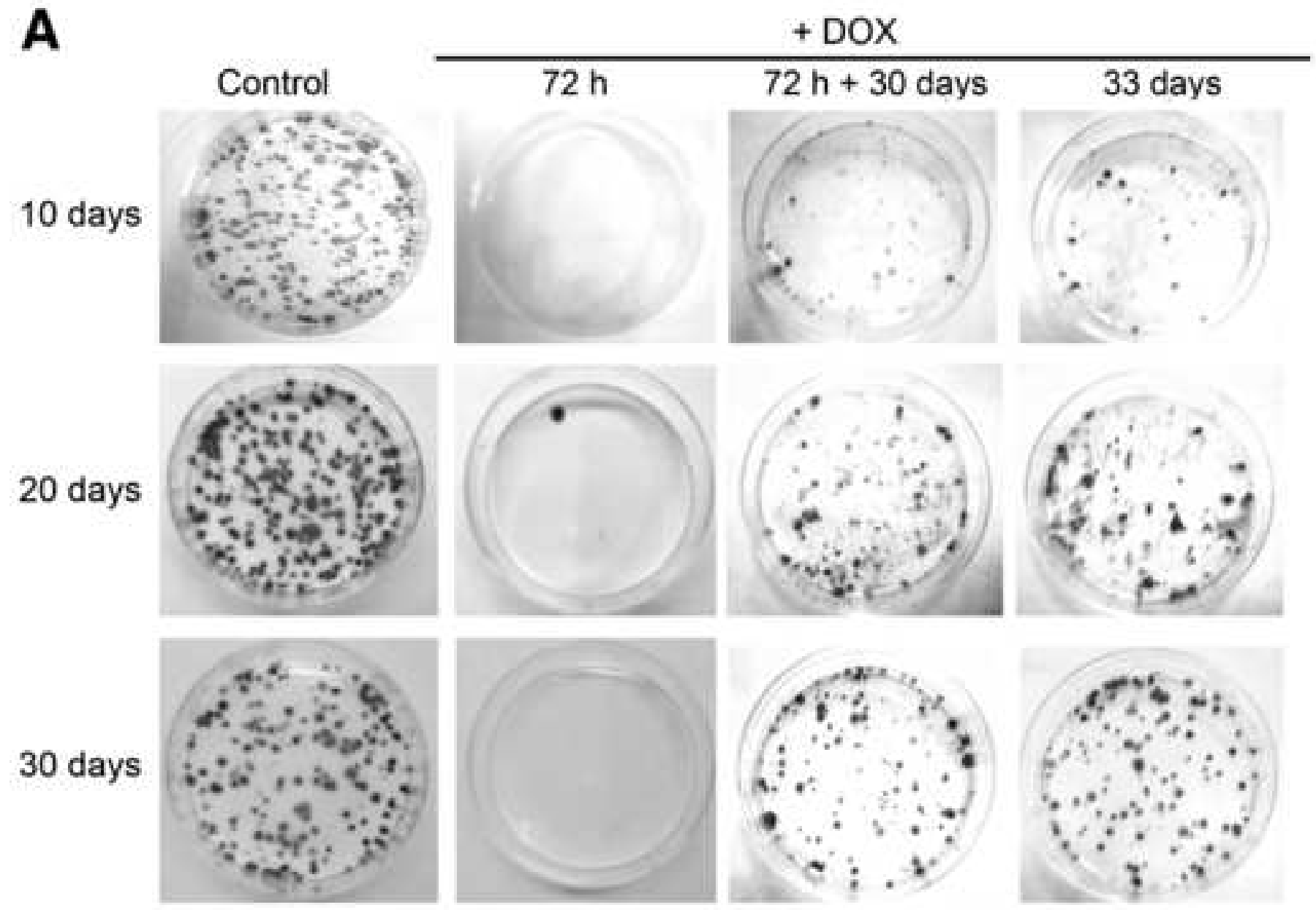

B

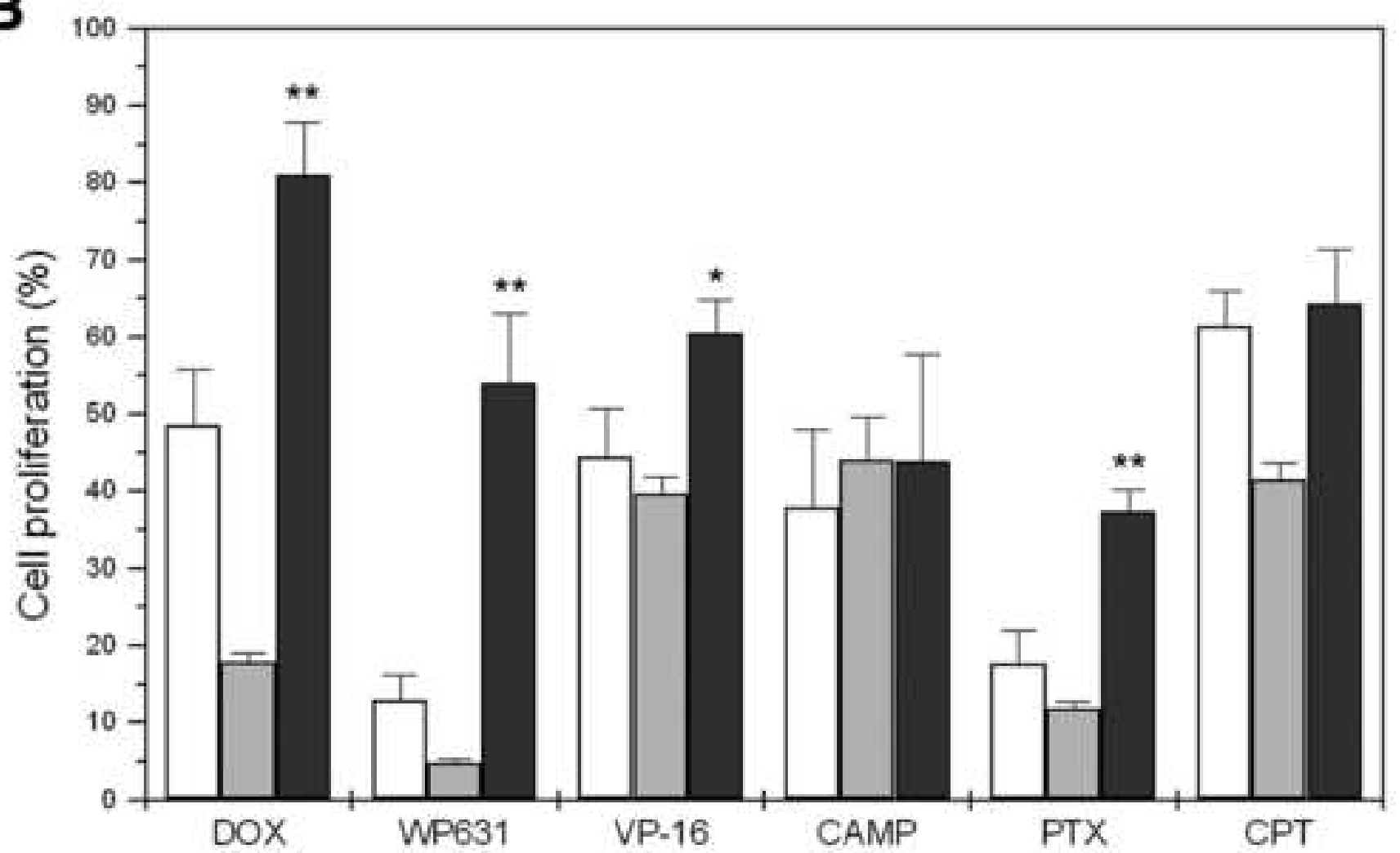

Figure 6 
Supplementary movie 1 . Time-lapse video analysis

Page 26 of 28 
更

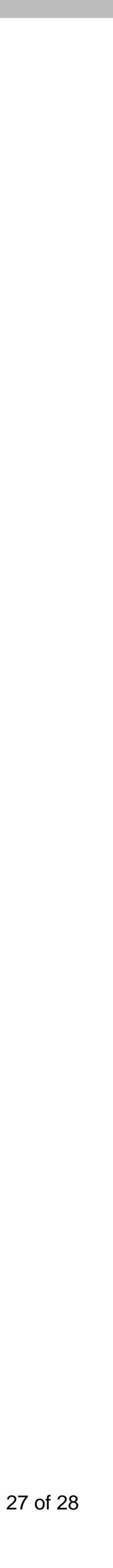

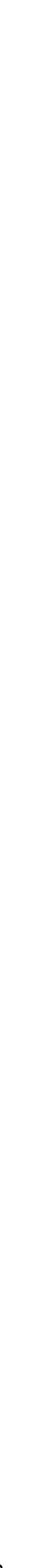



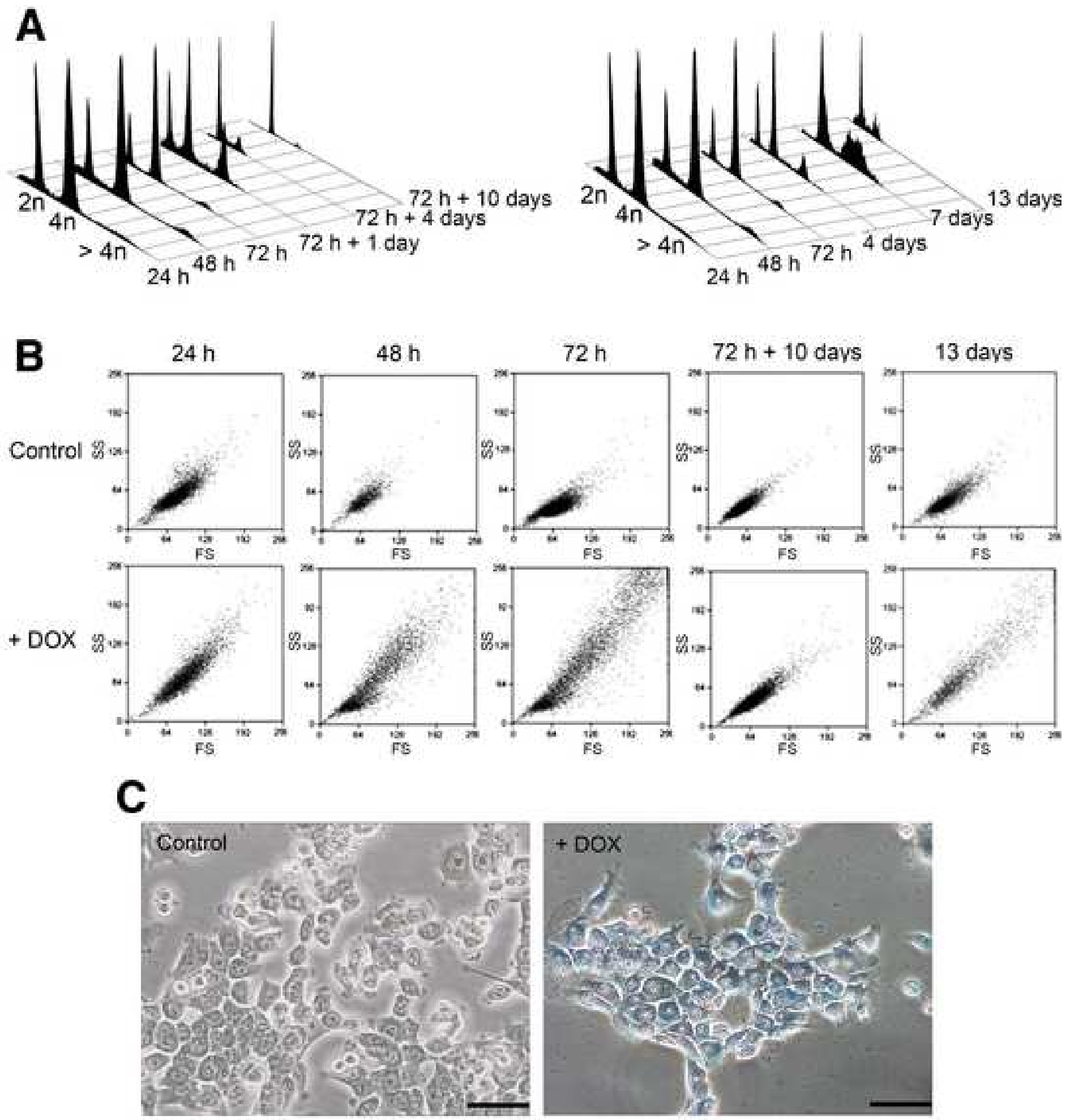

Figure1 